\title{
Perbedaan Sifat Fisik, Kimia dan Sensoris Tepung Umbi Suweg (Amorphophallus campamulatus BI) pada Fase Dorman dan Vegetatif
}

\author{
DOI: 10.18196/pt.2017.066.70-78
}

\author{
Umar Hafidz Asy'ari Hasbullah* dan Rini Umiyati \\ Program Studi Teknologi Pangan, Universitas PGRI Semarang, \\ Jalan Sidodadi Timur No. 24, Semarang Jawa Tengan 50125, Telp: +62 (024) 8316377, Fax: +62 (024) 8448217, \\ *Corresponding author, e-mail: umarhafidzah@gmail.com/umarhafidzah@upgris.ac.id
}

\begin{abstract}
ABSTRAK
Penelitian ini bertujuan untuk mempelajari perbedaan sifat fisik, kimia dan sensoris tepung suweg dari fase dorman dan vegetatif. Parameter fisik yang diuji meliputi rendemen, edible portion, bulk density, derajat kecerahan, particle size index, indeks penyerapan air dan indeks kelarutan air. Parameter kimia yang diuji meliputi kadar air, abu, lemak, protein, karbohidrat, pati dan gula reduksi. Parameter sensoris yang diuji meliputi uji hedonik warna dan aroma serta uji deskriptif warna dan aroma. Hasil penelitian menunjukkan bahwa karakter fisik tepung suweg dari fase dorman dan fase vegetatif berbeda nyata pada semua parameter. Rendemen, edible portion, bulk density, derajat kecerahan, dan particle size index fase dorman lebih tinggi dari fase vegetatif. Karakter kimia tepung suweg dari fase dorman dan fase vegetatif berbeda nyata kecuali lemak dan karbohidrat. Pati fase dorman lebih besar dari fase vegetatif, sedangkan gula reduksinya berkebalikan. Karakter sensoris tepung suweg dari fase dorman dan fase vegetatif berbeda nyata pada parameter hedonik warna, deskriptif warna dan deskriptif aroma. Panelis menilai tepung suweg yang dihasilkan dari fase vegetatif memiliki warna lebih coklat dan berbau cenderung lebih kuat dibandingkan fase dorman sehingga lebih tidak disukai warna dan aromanya. Tepung suweg sebaiknya dipilih dari fase dorman. Pemanfaatan tepung suweg disarankan untuk produk seperti cookies dan biskuit yang bisa ditambankan bahan perisa untuk menutupi adanya warna coklat dan aroma khas tepung suweg.

Kata kunci: Amorphophallus campanulatus, Tepung umbi, Suweg, Fase dorman
\end{abstract}

\begin{abstract}
This study aims to determine of differences in physical, chemical and sensory properties of suweg flour from the dormant and vegetative phases. Physical parameters include yield, edible portion, bulk density, brightness, particle size index, water absorption index and water solubility index. Chemical parameters include the moisture, ash, fat, protein, carbohydrates, starches and sugars reduction. Sensory parameters include hedonic test of color and aroma as well as descriptive test of color and aroma. The results showed that the physical characteristics of flour suweg dormant phase and vegetative phase significantly different at all parameters. Yield, edible portion, bulk density, brightness, particle size index of dorman phase higher than vegetative phase. Chemical characteristics from dormant phase and vegetative phase were significantly different at all parameters, except fat and carbohydrate. Starch contain in dorman phase higher than vegetative phase. But in contrast to the sugar reduction contain. Panellists assess the suweg flour produced from the vegetative phase has a more brown color and smells stronger than the dormant phase so it is less preferred color and aroma. Suweg flour should be selected from the dormant phase. Utilization of flour suweg is recommended for products such as cookies and biscuits that can be grown ingredients to cover the presence of brown and off flavor.
\end{abstract}

Keywords: Amorphophallus campanulatus, Yam flour, Elephant foot yam, Dormant phase

\section{PENDAHULUAN}

Suweg (Amorphophallus campanulatus) merupakan salah satu jenis umbi yang tumbuh liar di berbagai daerah di Indonesia. Tanaman ini belum banyak dieksplorasi dan biasa tumbuh subur dibawah naungan tanaman lain. Tanaman suweg biasa bertunas diawal musim kemarau dan pada akhir tahun dimusim kemarau umbinya bisa dipanen (Kasno dkk., 2009). Produktivitas tanaman suweg berkisar 47,61 ton/hektar (Suja,
2013). Suweg mempunyai prospek untuk dikembangkan sebagai sumber pangan berupa tepung.

Tepung umbi suweg memiliki kandungan karbohidrat yang tinggi. Beberapa peneliti melaporkan kandungan karbohidratnya 70,75\% (Srivastava dkk., 2014), 83,18 \% (Faridah, 2005), dan 85,82 \% (Septiani dkk., 2005). Hal ini menunjukkan bahwa tepung suweg berpotensi sebagai sumber karbohidrat. 
Tananam suweg selama hidupnya mengalami dua fase kehidupan yaitu fase pertumbuhan vegetatif dan fase dorman. Selama fase tersebut akan terjadi berbagai macam perubahan komponen di dalam tanaman ini, termasuk dalam umbinya (Pitojo, 2007). Supriyadi dkk., (2016) menyampaikan bahwa pemanenan di musim penghujan memberikan dampak karakteristik tepung suweg berbeda dengan pemanenan di musim kemarau. Umbi suweg mengalami fase vegetatif ketika musim hujan dan akan mengalami fase dorman ketika musim kemarau. Hal ini akan berdampak pada tepung umbi yang dihasilkan. Perubahan karakter ini perlu diidentifikasi karena dalam aplikasinya akan berpengaruh pada produk akhir yang dihasilkan. Berdasarkan uraian tersebut maka perlu dilakukan studi yang bertujuan untuk mengetahui dampak adanya fase dormansi dan fase vegetatif pada tanaman suweg terhadap sifat fisik, kimia dan sensoris tepung umbi suweg.

\section{BAHAN DAN METODE}

Bahan yang digunakan adalah umbi suweg yang di ambil ketika fase dormansi dan fase vegetatif diperoleh dari Kecamatan Banjarmangu, Kabupaten Banjarnegara, Jawa Tengah. Umbi suweg fase dorman diperoleh ketika musim kemarau setelah tanaman mati dan tanah tempat tumbuh mengering, sedangkan umbi suweg fase vegetatif diperoleh ketika tanaman suweg masih hidup dan berdaun hijau pada waktu akhir musim penghujan atau awal musim kemarau. Penelitian ini dilakukan menggunakan rancangan acak lengkap faktor tunggal yaitu fase hidup yang terdiri dari fase vegetatif dan fase dorman. Variabel terikat terdiri dari sifat fisik tepung, sifat kimia dan sifat sensoris.

\section{Pembuatan Tepung Umbi Suweg}

Prosedur pembuatan tepung umbi suweg mengacu Septiani, dkk. (2015) yang dimodifikasi tanpa perendaman $\mathrm{HCl}$ dan $\mathrm{CaCO} 3$. Umbi suweg dikupas, diiris dengan ketebalan $2 \mathrm{~cm}$, dan dicuci. Selanjutnya dikeringkan selama 5 jam pada suhu $60^{\circ} \mathrm{C}$. Kemudian ditepungkan dan diayak 60 mesh. Tepung suweg disimpan dalam plastik pada suhu kamar sampai sebelum dianalisis.

\section{Analisis Sifat Fisik Tepung Suweg}

Sifat fisik yang diukur dalam studi ini antara lain bulk density, warna tepung dianalisis intensitas kecerahan (L) dengan menggunakan chromameter (Konica Minolta Chromameter CR400) (Faridah, 2005), rendemen dan edible portion (Muchtadi dkk., 2013), indeks penyerapan air (IPA) dan indeks kelarutan air (IKA) dengan metode Anderson (Anderson dkk., 1969), dan particle size index (Bejarano dkk., 2007).

\section{Analisis Sifat Kimia Tepung Suweg}

Kadar air, abu, lemak, protein dianalisis dengan mengacu pada AOAC (2005). Karbohidrat by difference, kadar pati dan gula reduksi diukur menggunakan metode Sudarmadji dkk., (2010).

\section{Analisis Sifat Sensoris Tepung Suweg}

Sifat sensoris yang diamati adalah uji deskriptif dan uji hedonik terhadap parameter warna dan aroma. Pengujian deskriptif dilakukan dengan menggunakan panelis semi terlatih. Uji hedonik dilakukan oleh 25 panelis. Skor nilai warna deskriptif 1: tidak coklat, 2: agak coklat (coklat cerah), 3: cukup coklat (coklat muda), 4: coklat, 5: sangat coklat (coklat gelap). Skor nilai aroma deskriptif 1: tidak kuat, 2: agak kuat, 3: cukup kuat, 4: kuat, 5: sangat kuat. Skor nilai hedonik 1: sangat tidak suka, 2: tidak suka, 3: agak 
suka, 4: netral, 5: agak suka, 6: suka, 7: sangat suka.

Data hasil pengujian dianalisis dengan $t$ test. Apabila hasil analisis tersebut menunjukkan perbedaan antara perlakuan, maka dilanjutkan dengan uji Duncann multiple range test (DMRT) pada taraf $5 \%$. Pengujian dilakukan dengan bantuan software SPSS versi 16.0 (2007).

\section{HASIL DAN PEMBAHASAN}

Sifat Fisik Tepung Suweg

Sifat fisik dari tepung suweg yang dihasilkan dari fase dorman dan fase vegetatif disajikan pada Tabel 1. Umbi suweg yang digunakan berukuran 1 - 1,5 kg untuk fase dorman dan 1 - $2 \mathrm{~kg}$ untuk fase vegetatif. Kadar air umbi suweg fase dorman 77,24 $\pm 1,13 \%$, sedangkan kadar air umbi suweg fase vegetatif $83,2 \pm 0,63 \%$. Yadav dan Singh (2016) melaporkan bahwa kadar air umbi suweg 76,93 - 77,5 \%, sedangkan Datta dkk. (2014) melaporkan 66,08 \%. Berdasarkan Tabel 1 , tepung suweg yang berasal dari fase dorman memiliki rendemen yang lebih besar dan berbeda nyata dengan fase vegetatif. Hal ini dapat terjadi karena selama fase dorman terjadi akumulasi pati sebagai cadangan makanan hasil metabolisme yang akan digunakan untuk tumbuh dan berkembang ketika membentuk tunas (Pitojo, 2007). Nilai rendemen tepung suweg berkisar antara 11-15\% dari berat bahan. Rendemen yang didapatkan dari studi ini masih dibawah nilai rendemen hasil penelitian Richana dan Sunarti (2004) yang menghasilkan nilai rendemen $18 \%$. Rendemen tepung suweg yang dihasilkan tidak jauh berbeda dengan umbi ganyong $(11,4 \%)$, akan tetapi sangat jauh dibawah ubi kelapa (23,9\%) dan gembili (24,3\%) (Richana dan Sunarti, 2004).

Edible portion (EP) menunjukkan persentase bagian dari suatu bahan pangan yang dapat dimakan (Muchtadi dkk., 2013; USFDA, 2014). Hasil penelitian menunjukkan bahwa nilai EP umbi suweg yang dihasilkan dari fase dorman lebih besar dan berbeda nyata dengan fase vegetatif. Nilai EP berkisar antara 73-85 \%. EP dari komoditas umbi-umbian sangat bervariasi. $\mathrm{Hal}$ tersebut bergantung dari ketebalan lapisan kulit gabus dan korteks yang mendasarinya (Elzebroek, 2008). Nilai EP suweg ini setara dengan EP ubi jalar (81\%), kentang (81\%) dan yam (86 \%) (WHO, 2003).

\section{Tabel 1. Sifat Fisik Tepung Umbi Suweg}

\begin{tabular}{lcc}
\hline Parameter & Fase Dorman & Fase Vegetatif \\
\hline Rendemen (\%) & $14,83 \pm 1,08 \mathrm{a}$ & $10,91 \pm 0,46 \mathrm{~b}$ \\
Edible portion (\%) & $84,64 \pm 1,26 \mathrm{a}$ & $72,62 \pm 7.82 \mathrm{~b}$ \\
Bulk density ( $\mathrm{g} / \mathrm{ml})$ & $0,659 \pm 0,05 \mathrm{a}$ & $0,580 \pm 0,04 \mathrm{~b}$ \\
Particle size index & $0,5276 \pm 0,04 \mathrm{a}$ & $0,4638 \pm 0,03 \mathrm{~b}$ \\
$\mathrm{~L}$ & $58,78 \pm 1,95 \mathrm{a}$ & $53,79 \pm 1,61 \mathrm{~b}$ \\
IPA & $0,52 \pm 0,22 \mathrm{a}$ & $0,86 \pm 0,03 \mathrm{~b}$ \\
IKA & $0,325 \pm 0,17 \mathrm{a}$ & $0,071 \pm 0,08 \mathrm{~b}$ \\
\hline
\end{tabular}

Keterangan: Notasi huruf yang sama menunjukkan tidak beda nyata pada $\alpha=0.05$. Data disajikan \pm standar deviasi.

Bulk density (BD) menunjukkan porositas dari suatu bahan yang menyatakan jumlah rongga yang terdapat diantara partikel bahan (Purnomo dkk., 2015). Nilai BD sangat penting berkaitan dengan pengemasan, penyimpanan dan transportasi (Faridah, 2005). Hasil penelitian menunjukkan bahwa nilai BD tepung suweg yang diperoleh dari fase dorman berbeda nyata dengan fase vegetatif. BD fase dorman berkisar $0,659 \mathrm{~g} / \mathrm{ml}$, sedangkan fase vegetatif $0,58 \mathrm{~g} / \mathrm{ml}$. Hal ini dimungkinkan karena PSI tepung suweg fase dorman lebih besar dari fase vegetatif. Nilai BD tepung suweg ini lebih rendah dibandingkan dengan hasil penelitian Faridah (2005) yaitu 0,78 g/ml. Hasbullah dkk. (2017) melaporkan bahwa tepung suweg di beberapa kabupaten di Jawa Tengah memiliki nilai BD 0,38-0,65 g/ml. Apabila dibandingkan dengan tepung ubi jalar 6,83 
g/ml (Adeleke dan Odedeji, 2010) maka tepung suweg memiliki nilai BD yang rendah.

Particle size index (PSI) menunjukkan tingkat kehalusan tepung, yaitu semakin tinggi nilai nya maka semakin tinggi juga tingkat kehalusan tepung (Benjarano dkk, 2007). Hasil analisis ditunjukkan dalam Tabel 1. Nilai PSI tepung suweg yang dihasilkan dari fase dorman berbeda nyata dengan fase vegetatif. Tepung suweg dari fase dorman memiliki PSI (52,76 \%) yang lebih tinggi dibandingkan tepung suweg dari fase vegetatif (46,38 \%). Hal ini menunjukkan bahwa tepung suweg fase dorman memiliki tingkat kehalusan lebih tinggi dibandingkan tepung suweg fase vegetatif. Semakin halus partikel tepung akan berdampak terhadap derajat kecerahan warnanya yang semakin tinggi.

Indeks penyerapan air (IPA) tepung suweg disajikan dalam Tabel 1. Hasil penelitian menunjukkan bahwa nilai IPA tepung suweg dari fase dorman berbeda nyata dengan fase vegetatif. $\mathrm{Ni}$ lai IPA fase dorman $(0,65)$ lebih kecil dibandingkan fase vegetatif $(0,84)$. Hal ini menunjukkan bahwa tepung suweg dari fase vegetatif memiliki kemampuan dalam menyerap air yang lebih tinggi dibandingkan dengan fase dorman. Hasil penelitian ini jauh lebih rendah dibandingkan dengan nilai IPA tepung suweg hasil penelitian Richana dan Sunarti (2004) yang sebesar 4,13 g/g. Nilai IPA ini juga masih lebih rendah dari beberapa tepung umbi lainnya seperti tepung umbi gembili $1,91 \mathrm{~g} / \mathrm{g}$, tepung umbi ubikelapa 2,51 g/g dan tepung umbi ganyong 3,33 g/g, tepung tape 5,3-6,3 ml/g (Richana dan Sunarti, 2004; Widowati dkk., 1998).

Indeks kelarutan air (IKA) tepung suweg disajikan dalam Tabel 1. Hasil penelitian menunjukkan bahwa nilai IKA tepung suweg yang dihasilkan dari fase dorman berbeda nyata dengan fase vegetatif. Nilai IKA fase dorman lebih tinggi dari pada fese vegetatif. Nilai IKA sangat berkaitan dengan kandungan amilosa dan amilopektin. Tepung dengan kadar amilosa yang tinggi akan memiliki IKA yang tinggi. Hal ini disebabkan amilosa lebih mudah larut dari pada amilopektin (Widowati dkk., 1998). Sehingga dimungkinkan kandungan amilosa tepung suweg dari fase dorman lebih banyak dari pada fase vegetatif.

Derajat kecerahan (L) menunjukkan intensitas kecerahan gelap terang warna tepung suweg. Derajat kecerahan tepung dinyatakan sebagai nilai L pada chromameter. Nilai ini menunjukkan kemampuan memantulkan cahaya yang mengenai permukaan suatu bahan. Semakin tinggi nilai L maka derajat kecerahan tepung suweg semakin tinggi. Data hasil analisis disajikan dalam Tabel 1. Nilai L tepung suweg dari fase dorman berbeda nyata dengan fase vegetatif. Nilai L tepung suweg fase dorman lebih tinggi dari pada fase vegetatif. Hal ini menunjukkan bahwa warna tepung suweg dari fase dorman lebih cerah dibandingkan fase vegetatif. Hal ini dimungkinkan terjadi karena ukuran partikel tepung suweg fase dorman lebih halus dibandingkan fase vegetatif. Ukuran partikel yang semakin halus dinyatakan dengan nilai PSI yang semakin tinggi. Selain itu dimungkinkan juga karena adanya browning pada tepung suweg oleh reaksi gula reduksi dan asam amino. Tepung suweg fase vegetatif memiliki kandungan gula reduksi dan protein lebih besar dari fase dorman (Tabel 2). Umumnya konsumen lebih menyukai tepung dengan derajat kecerahan lebih tinggi. Tepung suweg yang dihasilkan memiliki derajat kecerahan yang rendah, sehingga disarankan untuk diaplikasikan kedalam produk yang umumnya berwarna gelap. Nilai derajat kecerahan tepung suweg ini lebih kecil dari tepung suweg hasil penelitian Faridah (2005) yaitu 60,6. Hal ini dimungkinkan karena suhu pengeringan yang 
digunakan Faridah (2005) lebih rendah $10^{\circ} \mathrm{C}$ dari pada penelitian ini dan dengan waktu pengeringan yang lebih lama yaitu 18 jam. Beberapa peneliti lainnya menyatakan kecerahan tepung suweg dengan color reader memiliki nilai 57,7 \% (Septiani dkk., 2015) dan 39 \% (Richana dan Sunarti, 2004). Septiani melakukan pengeringan dengan suhu $60^{\circ} \mathrm{C}$ selama 5 jam. Sedangkan Richana dan Sunarti, (2004) melakukan pengeringan dengan suhu $50^{\circ} \mathrm{C}$ selama 24 jam.

\section{Sifat Kimia Tepung Suweg}

Analisis sifat kimia tepung suweg yang dihasilkan dari fase dorman dan vegetatif disajikan dalam Tabel 2. Nilai kadar air tepung suweg yang dihasilkan dari fase dorman berbeda nyata dengan fase vegetatif (Tabel 2). Kadar air tepung suweg fase dorman $(6,54 \%)$ lebih besar dari pada fase vegetatif $(5,48 \%)$. Nilai kadar air tersebut lebih rendah dibandingkan hasil penelitian Richana dan Sunarti (2004) yaitu 9,4 \%. Sementara nilai kadar air tepung suweg menurut peneliti lainnya 6,57 \% (Septiani dkk., 2015); 9,4 \% (Mukhlis, 2003) dan 4,7 \% (Faridah, 2005). Kadar air menjadi salah satu parameter penting dalam menentukan mutu tepung. Hal tersebut disebabkan risiko kerusakan tepung akan meningkat pada kadar air yang tinggi. Nilai kadar air tepung suweg ini hampir sama dibandingkan dengan tepung umbi lainnya seperti tepung umbi ganyong $(6,69 \%)$ dan tepung umbi gembili $(6,44$ $\%)$. Akan tetapi kadar air tepung suweg ini lebih rendah dibanding dengan tepung ubikelapa yaitu 11,06 \% (Richana dan Sunarti, 2004).

Kadar abu tepung suweg disajikan dalam Tabel 2. Kadar abu menunjukkan kandungan mineral yang terdapat dalam bahan (Winarno, 1997). Hasil analisis menunjukkan bahwa kadar abu tepung suweg yang dihasilkan dari fase dorman berbeda nyata dengan fase vegetatif. Nilai kadar abu fase dorman lebih kecil dibandingkan fase vegetatif. Kadar abu tepung suweg ini lebih tinggi dibandingkan SNI untuk produk tepung terigu dimana batas maksimum kadar abu ialah 0,7 \%. Hasil yang berbeda dilaporkan Richana dan Sunarti (2004) yang menyatakan kadar abu tepung suweg 3,8 \%. Sementara Septiani dkk. (2015) melaporkan kadar abu tepung suweg 3,32\% dan Faridah (2005) melaporkan kadar abu tepung suweg 4,7 \%. Kandungan mineral bahan segar asal tanaman sangat dipengaruhi oleh kondisi mineral tanah tempat tumbuhnya. Apabila dibandingkan dengan tepung dari jenis umbi yang lain maka kadar abu tepung suweg masih lebih tinggi. Tepung ganyong memiliki kadar abu 2,89\%, tepung ubikelapa memiliki kadar abu 3,56\%, dan tepung gembili memiliki kadar abu 2,87 \% (Richana dan Sunarti, 2004).

Kadar lemak tepung suweg disajikan dalam Tabel 2. Hasil analisis menunjukkan bahwa kadar lemak tepung suweg yang dihasilkan dari fase dorman tidak berbeda nyata dengan fase vegetatif. Nilai kadar lemak berkisar 1,02 - 1,09 \%. Kadar lemak tepung suweg ini lebih tinggi dibandingkan hasil penelitian Faridah (2005) sebesar 0,28 \%, Richana dan Sunarti (2000) sebesar 1,64 \%, Septiani dkk. (2015) sebesar 0,39\%.

Tabel 2. Sifat Kimia Tepung Umbi

\begin{tabular}{lcc}
\hline Parameter & Fase Dorman & Fase Vegetatif \\
\hline Air (\%) & $6,54 \pm 0,13 \mathrm{a}$ & $5,48 \pm 0,39 \mathrm{~b}$ \\
Abu (\%) & $5,13 \pm 0,42 \mathrm{a}$ & $5,69 \pm 0,19 \mathrm{~b}$ \\
Lemak (\%) & $1,02 \pm 0,13 \mathrm{a}$ & $1,09 \pm 0,15 \mathrm{a}$ \\
Protein (\%) & $6,45 \pm 1,09 \mathrm{a}$ & $7,77 \pm 1,35 \mathrm{~b}$ \\
Karbohidrat by difference (\%) & $80,85 \pm 1,05 \mathrm{a}$ & $79,97 \pm 1,57 \mathrm{a}$ \\
Gula reduksi (\%) & $1,33 \pm 0,15 \mathrm{a}$ & $1,83 \pm 0,38 \mathrm{~b}$ \\
Pati (\%) & $88,7 \pm 3,28 \mathrm{a}$ & $70,31 \pm 9,41 \mathrm{~b}$ \\
\hline
\end{tabular}

Keterangan: Notasi huruf yang sama menunjukkan tidak beda nyata pada $\alpha=0.05$. Data disajikan \pm standar deviasi.

Kadar protein tepung suweg disajikan dalam Tabel 2. Hasil analisis menunjukkan bahwa 
tepung suweg yang dihasilkan dari fase dorman berbeda nyata dengan fase vegetatif. Nilai kadar protein tepung suweg fase dorman $(6,45 \%)$ lebih rendah dibandingkan dengan fase vegetatif $(7,77$ $\%)$. Hal ini dimungkinkan karena ketika fase dorman semua cadangan makanan dalam umbi disimpan dalam bentuk karbohidrat, sehingga ketika ditepungkan akan menyebabkan tingginya persen karbohidrat dan rendahnya protein. Selain itu ketika fase vegetatif masih dimungkinkan masih banyak terdapat enzim yang merupakan protein sehingga kadar proteinnya lebih tinggi dari fase dorman. Faridah (2005) melaporkan bahwa tepung umbi suweg memiliki kadar protein 7,2 \%. Sementara Richana dan Sunarti (2000) melaporkan sebesar 5,22\%. Septiani dkk. (2015) melaporkan kadar protein tepung suweg sebesar 3,91\%.

Kandungan karbohidrat tepung suweg disajikan dalam Tabel 2. Hasil analisis menunjukkan bahwa tepung suweg yang dihasilkan dari fase dorman tidak berbeda nyata dengan fase vegetatif. Nilai kandungan karbohidrat tepung suweg berkisar 79,97 - 80,85 \%. Hal ini menunjukkan bahwa tepung suweg potensial menjadi sumber karbohidrat. Kadar karbohidrat tepung suweg ini masih lebih rendah dibandingkan hasil penelitian Faridah (2005) sebesar 83,18 \% dan Septiani dkk. (2015) sebesar 85,82 \%. Akan tetapi masih lebih tinggi dari hasil penelitian Ardhiyanti (2008) sebesar 77,81\% dan Yadav dan Singh (2016) sebesar 73,86 \%.

Kandungan pati tepung suweg disajikan dalam Tabel 2. Kadar pati menjadi salah satu parameter mutu produk tepung untuk kebutuhan pangan dan non pangan. Hasil analisis menunjukkan bahwa kandungan pati tepung suweg yang dihasilkan dari fase dorman berbeda nyata dengan fase vegetatif. Nilai kandungan pati tepung suweg fase dorman lebih besar dibandingkan fase vegetatif. Hal ini disebabkan pati digunakan sebagai cadangan makanan selama fase dorman dan juga sebagai sumber makanan ketika awal masa pembentukan tunas dan pertumbuhan awal tanaman (Pitojo, 2007). Kadar pati tepung suweg ini jauh lebih banyak dari kadar pati tepung suweg hasil penelitian Richana dan Sunarti (2004) yaitu 39,36 \%. Begitu pula dengan kadar pati tepung umbi lainnya seperti ganyong $(40,18 \%)$, ubi kelapa $(52,25$ \%) dan gembili (42,16 \%). Santosa dkk. (2002) melaporkan bahwa kandungan pati umbi suweg 3,6-11,4 g/100 g berat basah. Kadar pati umbi dipengaruhi umur panen umbi. Kadar pati yang telah optimum akan dikonversi secara perlahan menjadi serat (Wahid dkk, 1992).

Kandungan gula reduksi tepung suweg disajikan dalam Tabel 2. Hasil analisis menunjukkan bahwa gula reduksi tepung suweg yang dihasilkan dari fase dorman berbeda nyata dengan fase vegetatif. Kandungan gule reduksi fase vegetatif lebih tinggi dibandingkan fase dorman. Gula reduksi yang rendah pada tepung suweg fase dorman dimungkinkan berdampak terhadap derajat kecerahan tepung yang lebih tinggi dari fase vegetatif. Gula reduksi akan menyebabkan browning non enzimatis karena bereaksi dengan asam amino dari protein selama proses pengeringan. Nilai ini masih lebih tinggi bila dibandingkan dengan kandungan gula umbi suweg hasil penelitian Srivastava dkk. (2014) sebesar 1,16\% dan juga Suja (2013) sebesar 0,78 \%. Kandungan gula reduksi tepung suweg ini masih lebih rendah dibandingkan hasil penelitian Lukitaningsih dkk. (2012) sebesar 4,34\%, sedangkan tepung ubi jalar ungu sebesar 3,15 \% (Nindyarani dkk., 2011).

\section{Sifat Sensoris}

Hasil analisis sifat sensoris tepung suweg yang 
dihasilkan dari fase dorman dan vegetatif yang meliputi uji hedonik dan uji deskriptif disajikan dalam Tabel 3.

Sifat sensoris untuk uji hedonik (kesukaan) warna tepung suweg disajikan dalam Tabel 3. Hasil analisis menunjukkan bahwa skor hedonik warna tepung suweg yang dihasilkan dari fase dorman berbeda nyata dengan fase vegetatif. Panelis menyatakan bahawa tepung suweg dari fase dorman lebih disukai dibandingkan dengan fase vegetatif. Hal ini dimungkinkan karena warna tepung suweg fase vegetatif cenderung lebih coklat daripada fase dorman. Selain itu juga dimungkinkan karena derajat kecerahan tepung suweg fase dorman lebih tinggi yang ditunjukkan dengan nilai $\mathrm{L}$ yang lebih tinggi dari fase vegetatif.

Sifat sensoris untuk uji hedonik (kesukaan) aroma tepung suweg disajikan dalam Tabel 3. Hasil analisis menunjukkan bahwa skor hedonik aroma tepung suweg yang dihasilkan dari fase dorman tidak berbeda nyata dengan fase vegetatif. Panelis menyatakan bahawa tepung suweg dari fase dorman dan fase vegetatif cenderung kearah tidak disukai. Hal ini dimungkinkan karena tepung suweg memiliki aroma khas yang cenderung kuat. Hal ini bersesuaian dengan Hasbullah (2016) yang menyatakan bahwa tepung suweg yang dihasilkan dari beberapa kabupaten di Karesidenan Surakarta memiliki aroma yang cukup kuat sehingga menurunkan skor kesukaan panelis terhadap parameter aroma.

Sifat sensoris untuk uji deskriptif warna tepung suweg disajikan dalam Tabel 3. Hasil analisis menunjukkan bahwa skor deskriptif warna tepung suweg yang dihasilkan dari fase dorman berbeda nyata dengan fase vegetatif. Panelis menyatakan bahawa tepung suweg dari fase vegetatif memiliki warna yang lebih coklat dibandingkan fase dorman. Warna coklat pada tepung suweg ini diduga dipengaruhi kandungan fenol dalam umbi. Hal ini diperkuat oleh Ramalingam dkk (2010) dan Suja (2013) yang menyatakan bahwa dalam umbi suweg mengandung senyawa fenol. Panja dan Adhikary (2016) membuktikan beberapa kultivar umbi suweg mengandung total fenol tinggi yaitu 50,44 mg/100g. Fenol akan menyebabkan terjadi reaksi pencoklatan enzimatis. Enzim fenol oksidase akan bereaksi dengan oksigen diudara yang akan mengubah fenol menjadi hidroksi quinon yang berwarna coklat. Enzim ini akan kontak langsung dengan substratnya yaitu fenol ketika proses pengupasan dan perajangan umbi (Muchtadi dkk., 2013). Disisi lain dimungkinkan terjadi reaksi maillard selama proses pembuatan tepung. Reaksi maillard ini terjadi karena gugus reduksi gula reduksi bereaksi dengan gugus amin dari protein dan dengan adanya panas selama pengeringan maupun penepungan sehingga menghasilkan warna coklat. Hal ini bersesuaian dengan adanya kandungan gula reduksi dan protein dalam tepung dan umbi suweg. Beberapa peneliti juga menyatakan adanya gula reduksi dan protein dalam suweg seperti Srivastava dkk. (2014), Suja (2013) dan Lukitaningsih dkk. (2012). Hal ini juga bersesuaian dengan Hasbullah (2016) yang menyatakan sebagian besar tepung suweg dari Karesidenan Surakarta mempunyai warna yang coklat.

Tabel 3. Sifat Sensoris Tepung Umbi Suweg

\begin{tabular}{lll}
\hline Parameter & Fase Dorman & Fase Vegetatif \\
\hline Hedonik warna & $4,54 \pm 1,21 \mathrm{a}$ & $2,96 \pm 0,69 \mathrm{~b}$ \\
Hedonik aroma & $3,67 \pm 1,05 \mathrm{a}$ & $3,12 \pm 1,15 \mathrm{a}$ \\
Deskriptif warna & $2,17 \pm 0,48 \mathrm{a}$ & $3,25 \pm 0,44 \mathrm{~b}$ \\
Deskriptif aroma & $2,79 \pm 0,67 \mathrm{a}$ & $3,92 \pm 0,65 \mathrm{~b}$ \\
\hline
\end{tabular}

Keterangan: Notasi huruf yang sama menunjukkan tidak beda nyata pada $\alpha=0.05$. Data disajikan \pm standar deviasi. Semakin tinggi nilai skor hedonik menunjukkan kesukaan panelis semakin meningkat. Semakin tinggi skor nilai warna deskriptif menunjukkan semakin coklat tua. Semakin tinggi skor nilai aroma deskriptif menunjukkan aroma yang semakin kuat. 
Sifat sensoris untuk uji deskriptif aroma tepung suweg disajikan dalam Tabel 3. Hasil analisis menunjukkan bahwa skor deskriptif aroma tepung suweg yang dihasilkan dari fase dorman berbeda nyata dengan ase vegetatif. Panelis menyatakan bahawa tepung suweg dari fase vegetatif memiliki aroma yang lebih kuat dibandingkan fase dorman. Aroma tepung suweg ini sangat berkaitan dengan banyaknya senyawa volatil yang terdapat pada tepung. Proses pengeringan diduga memberikan kontribusi dalam faktor aroma tepung. Reaksi maillard yang diinisiasi panas akan menyebabkan gula-gula reduksi bereaksi dengan asam amino yang terdapat dalam umbi (Winarno, 1997). Hasil reaksi maillard ini akan menghasilkan senyawa volatil yang berkontribusi terhadap aroma tepung suweg. Selain itu juga dimungkinkan adanya asam-asam lemak yang turut berkontribusi terhadap aroma tersebut. Lukitaningsih dkk. (2012) menyatakan bahwa dalam umbi suweg terdapat asam linoleat dan asam palmitat. Asam linoleat ini lebih banyak jumlahnya dibandingkan asam palmitat. Asamasam lemak khususnya asam linoleat merupakan prekusor senyawa volatil melalui reaksi oksidasi. Asam-asam lemak hasil pemecahan lemak dan produk oksidasi dari asam lemak berkontribusi terhadap perkembangan off flavor bahan pangan (Shahidi, 2000).

Berdasarkan semua data penelitian yang didapatkan maka dapat direkomendasikan bahwa waktu panen umbi suweg yang dianjurkan untuk diolah menjadi tepung ialah ketika fase dorman. Ketika fase dorman akan dihasilkan tepung suweg dengan rendemen yang lebih banyak, derajat kecerahan yang lebih tinggi, kadar gula reduksi yang lebih rendah, kadar pati yang lebih tinggi dan intensitas aroma yang lebih rendah dibandingkan fase vegetatif.

\section{SIMPULAN}

Perbedaan fase dorman dan vegetatif menyebabkan perbedaan sifat fisik, kimia dan sensoris tepung suweg yang dihasilkan. Tepung suweg fase dorman memiliki keunggulan dibandingkan fase vegetatif. Hal ini tercermin dari tingginya rendemen dan nilai L, rendahnya kadar gula reduksi dan aroma khas tepung suweg fase dorman daripada fase vegetatif. Tepung suweg direkomendasikan untuk digunakan sebagai bahan pangan seperti biskuit maupun cookies karena warna coklat dapat ditutup dengan penambahan coklat dan juga aroma khas dapat ditutup dengan pemberian perisa.

\section{UCAPAN TERIMAKASIH}

Terima kasih kepada Lembaga Penelitian dan Pengabdian kepada Masyarakat (LPPM) Universitas PGRI Semarang yang telah membiayai penelitian ini melalui program hibah penelitian dosen pemula.

\section{DAFTAR PUSTAKA}

Adeleke, R.O. dan J.O. Odedeji. 2010. Functional Properties of Wheat and Sweet Potato Flour Blends. Pakistan Journal of Nutrition 9(6): 535-538.

Anderson RA, HF. Conway, VF. Pfeifer, EL. 1969. Griffin. Gelatinization of corn grits by roll and extrusion cooking. J. Cereal Science 14:4-12.

AOAC. 2005. Official of Analysis of Official Analytical Chemistry. AOAC inc. Arlington. USA.36 p.

Ardhiyanti, SD. 2008. Daya Hipokolesterolemik Tepung Umbi Suweg (Amorphophallus campanulatus) pada Tikus Percobaan (Rattus norvegicus). Skripsi. Fakultas Teknologi Pertanian IPB. Bogor.

Bejarano, PIA, NMV. Montoya, EOC. Rodriguez, GM. Carillo, RM. Escobedo, JAL. Valenzuela, JAG. Tiznado, CR. Moreno. 2007. Tempeh Flour from Chickpeas (Cicer carietinum L.) Nutritional and Physicochemical Properties. Food Chem 10(6):106112.

Datta G., Basu S., Das M., Sen A., Choudhury UR. 2014. Analysis of Complete Nutritional Profile of Amorphophallus Campanulatus Tuber Cultivated in Howrah District of West Bengal, India. Asian J Pharm Clin Res 7(3):25-29.

Elzebroek, ATG. 2008. Guide to Cultivated Plants. CABI. USA. 50 p. 
Faridah, DN. 2005. Sifat Fisiko-kimia Tepung Suweg (Amorphopallus campanulatus B1) dan Indeks Glikemiksnya. Jurnal. Teknol. dan Industri Pangan 8(3):254-259.

Hasbullah, UHA. 2016. Sifat Sensoris dan Principal Component Analysis Tepung Suweg di Karisidenan Surakarta. Jurnal IImiah Teknosains 2(2):107-111.

Hasbullah, UHA., F. Nurdyansyah, B. Supriyadi, R. Umiyati, dan RMD. Ujianti. 2017. Sifat Fisik dan Kimia Tepung Umbi Suweg (Amorphophallus campamulatus BI) di Jawa Tengah. Jurnal Pangan dan Gizi 7(1):59-65.

Kasno, A. 2009. Agribisnis Tanaman Suweg. Gema Pertapa. Jakarta. 24 hal.

Lukitaningsih, E., Rumiyati, I. Puspitasari, dan M. Christiana. 2012. Analysis of Macronutriencontent, Glycemic Index and Calcium Oxalate Elimination In Amorphophallus campanulatus (Roxb.). Jurnal Natural 12(2):1-8.

Muchtadi, TR., Sugiyono, dan F. Ayustaningwarno. 2013. IImu Pengetahuan Bahan Pangan. Alfabeta. Bandung. 44 hal.

Mukhis, F. 2003. Karakterisasi Sifat Fisikokimia Tepung dan Pati Umbi Ganyong (Canna edulis Kerr.) dan Suweg (Amorphophallus campanulatus Bl.) serta Sifat Penerimaan Amilase terhadap Pati. Skripsi. FakultasTeknologi Pertanian IPB. Bogor.

Nindyarani, AK., Sutardi, Suparmo. 2011. Karakteristik Kimia, Fisik dan Inderawi Tepung Ubi Jalar Ungu (Ipomoea batatas Poiret) dan Produk Olahannya. Agritech 31(4):273-280.

Panja, P. dan S. Adhikary. 2016. Diversity of Physical and BioChemical Properties in Some Elephant Foot Yam (Amorphophallus Paeoniifolius) Cultivars at Harvest Fresh Stage. The Bioscan 11(2): 1193-1198.

Pitojo, S. 2007. Suweg. Penerbit Kanisius. Yogyakarta. 56 hal.

Purnomo, EP., AN. Ginanjar, F. Kusnandar dan C. Andriani. 2015. Karakteristik Sifat Fisikokimia Tepung Kacang Hitam dan Aplikasinya pada Brownies Panggang. Jurnal Mutu Pangan 2(1):26-33.

Ramalingam, R., KH. Bindu, BB. Madhavi, AR. Nath, D. Banji. 2010. Phyto Chemical and Anthelmintic Evaluation of Corm of Amorphophallus Campanulatus. International Journal of Pharma and Bio Sciences 6(2):1-9.

Richana, N dan T.C Sunarti, 2004. Karakterisasi Sifat Fisikokimia Tepung Umbi dan Tepung Pati dari Umbi Ganyong, Suweg, Ubi Kelapa, dan Gembili J. Pascapanen 1(1):29-37.

Santosa, E., N. Sugiyama, MA. Chozin, AP. Lontoh, S. Sudiatso, S. Kawabata, S. Hikosaka, Sutoro, A. Hidayat. 2002. Morphological and Nutritional Characterization of Elephant Foot Yam in Indonesia. Japanese Journal of Tropical Agriculture 46(4):265-271.

Septiani, D., Y. Hendrawan dan R. Yulianingsih. 2005. Uji Karakteristik Fisik, Kimia Dan Organoleptik Pembuatan Tepung Umbi Suweg (Amorphophallus campanulatus B) Sebagai Bahan Pangan Alternatif. Jurnal Bioproses Komoditas Tropis $3(1): 11-18$.

Shahidi, F. 2000. Lipids in Flavor Formation in Flavor Chemistry. ACS Symposium Series. 756 (3): 24-43. doi: 10.1021/bk2000-0756.ch003.
Srivastava, S., D. Verma, A. Srivastava, SS. Tiwari, B. Dixit, SRS dan AKS. Rawat. 2014. Phytochemical and Nutritional Evaluation of Amorphophallus campanulatus (Roxb.) Blume Corm. J Nutr Food Sci 4(3): 274. doi: 10.4172/2155-9600.1000274.

Sudarmadji, S., B. Haryono dan Suhardi. 2010. Prosedur Analisa untuk Bahan Makanan dan Pertanian. Liberty. Yogyakarta. 160 hal.

Suja, G. 2013. Comparison of Tuber Yield, Nutritional Quality and Soil Health Under Organic Versus Conventional Production in Tuberous Vegetables. Indian Journal of Agricultural Sciences 83(11): 1153-1158.

USFDA. 2014. Elemental Analysis Manual (EAM) for Food and Related Products. Diakses 10 Februari 2017. http://www. fda.gov/Food/FoodScienceResearch/LaboratoryMethods/ ucm2006954.htm.

Utami, PU. 2009. Peningkatan Mutu Pati Ganyong (Canna edulis Ker) melalui Perbaikan Proses Produksi. Skripsi. Fakultas Teknologi Pertanian IPB. Bogor.

Wahid AS, N Richana dan Djamaluddin C. 1992. Pengaruh Umur Panen dan Pemupukan Terhadap Hasil dan Kualitas Ubi Kayu Varietas Gading dan Adira-4. Titian Agronomi. Bul. Pen. Agr. 1: $11-15$.

WHO. 2003. Unit weight edible portion. Diakses 10 Februari 2017. http://www.who.int/foodsafety/chem/acute_hazard_db3.pdf.

Widowati, S., AB. Ahza dan MEW. Umaryadi. 1998. Evaluasi sifat fisiko-kimia tepung tape ubi kayu. Prosiding Seminar Nasional Teknologi Pangan dan Gizi. PATPI. 32-41.

Winarno, F.G. 1997. Kimia Pangan dan Gizi. PT Gramedia Pustaka Utama. Jakarta. 253 hal.

Yadav, A. dan S. Singh. 2016. Physicochemical Properties of Selected Varieties of Elephant Foot Yam (Amorphophallus paeoniifolius). International Journal of Home Science 2(3): 353-357. 